Full length Article

\title{
Economic policy uncertainty: Persistence and cross-country linkages
}

\author{
Emmanuel Joel Aikins Abakah ${ }^{a}$, Guglielmo Maria Caporale ${ }^{\text {, *, }}$ \\ Luis Alberiko Gil-Alana ${ }^{\mathrm{c}}$ \\ ${ }^{\text {a }}$ The University of Adelaide Business School, Australia \\ ${ }^{\mathrm{b}}$ Brunel University London, UK \\ ${ }^{\mathrm{c}}$ University of Navarra, Spain
}

\section{A R T I C L E I N F O}

\section{JEL classifications:}

C15

C32

C51

C52

E60

Keywords:

Economic policy uncertainty

Persistence

Long memory

Fractional integration

Fractional cointegration

\begin{abstract}
A B S T R A C T
This paper provides new evidence on the stochastic behaviour of the EPU (Economic Policy Uncertainty (EPU) index constructed by Baker et al. (2016) in six of the biggest economies (Canada, France, Japan, US, Ireland, and Sweden), and also on cross-country linkages, over the period from January 1985 to October 2019. For this purpose, it uses fractional integration/ cointegration methods to measure the degree of persistence of the EPU and whether there exists a long-run equilibrium relationship linking the individual indices. This framework is much more general than the standard approaches based on the $\mathrm{I}(0) / \mathrm{I}(1)$ dichotomy since it allows for fractional values of the integration/cointegration parameter and therefore does not impose restrictive assumptions on the dynamic behaviour of the individual series and their linkages. EPU is found to be in most cases a non-stationary, mean-reverting series which is characterised by long memory. Several breaks are also detected in each country. Finally, there is very little evidence of crosscountry linkages. Our analysis provides fresh insights into the degree of persistence and the transmission of EPU shocks and has implications both for investors having to make risk management decisions and choose investment strategies and policymakers having to design effective macroeconomic policies.
\end{abstract}

\section{Introduction}

Economic activity and the behaviour of economic agents at the household and firm level are greatly influenced by uncertainty (Bernanke, 1983; Carroll, 1997; Bansal and Yaron, 2004; McDonald and Siegel, 1986; Dixit and Pindyck, 1994; Bloom et al., 2001; Dixit, 1989). In particular, in recent years the role played by economic policy uncertainty (EPU thereafter) in driving macroeconomic fluctuations has been one of the most widely discussed issues among academics, policy-makers and practitioners. In his well-known study, Bloom (2009) estimated a time-varying model using firm-level data and concluded that higher uncertainty can generate sharp recessions, and subsequent swift rebounds, in both output and employment, owing to the 'wait and see' attitude of firms making investment and hiring decisions subject to uncertainty.

Other studies provide mixed evidence on the impact of EPU on economic activity. For example, Baker et al. (2016), using a structural VAR model, showed that it results in statistically significant declines in employment, investment and industrial production

\footnotetext{
* Corresponding author at: Department of Economics and Finance, Brunel University London, Uxbridge UB8 3PH, UK.

E-mail address: Guglielmo-Maria.Caporale@brunel.ac.uk (G.M. Caporale).
} 
both in the US economy and in an international setting. Gulen and Ion (2016) and Kang et al. (2014) (in the case of the US) and Fernandez and Rodrik (1991) (for the developing countries) found that uncertainty causes capital investment and productivity to plummet. Leduc and Liu (2016) reported that an uncertainty shock increases unemployment and at the same time lowers inflation. Pastor and Veronesi (2012) showed that higher policy uncertainty is associated with lower stock prices, higher volatility and higher correlations among stock returns. Ko and Lee (2015) found that an increase in EPU reduces stock prices. Thiem (2018) analysed the interdependence of policy uncertainty from 1985 to 2017 across six categories of US economic policy (monetary, fiscal, healthcare, national security, regulatory, and trade policy) using the Diebold and Yilmaz $(2012,2014)$ connectedness index. Sahinoz and Cosar (2018) concluded that EPU has an adverse effect on economic growth and investment. Solarin and Gil-Alana (2021) and Gil-Alana and Payne (2020) investigated on the degree of persistence in EPU in various countries.

The papers mentioned above analyse EPU in the context of individual economies. However, it is also of interest to establish to what extent EPU shocks originating in one country might affect uncertainty and the business cycles in other countries. For instance, some studies have investigated the impact of EPU spillovers on financial markets, especially stock markets (Gulen and Ion, 2016; Kang et al., 2014). Balcilar et al. (2020a, 2020b) analysed the transmission of EPU shocks from the US and the EU to various Asian economies using a quantile vector autoregression (QVAR) approach. One would expect that especially smaller open economies with perfect capital mobility, a high degree of openness and a sizable financial sector should be influenced by the international transmission of EPU shocks.

The present paper aims to shed new light on this issue by using fractional integration and cointegration techniques to examine the statistical properties of individual EPU series as well as cross-country linkages for a set of six (both large and small) economies, namely Canada, France, Japan, US, Ireland, and Sweden. This framework is much more general than the standard approaches based on the I (0)/I(1) dichotomy since it allows for fractional values of the integration/cointegration parameter and therefore does not impose restrictive assumptions on the dynamic behaviour of the individual series and their linkages (for applications to other economic and financial variables see Cheung and Lai, 1993; Baillie and Bollerslev, 1994; Baillie, 1996; Dueker and Startz, 1998; Caporale and Gil-Alana, 2002; Gil-Alana et al., 2020a, b; Abakah et al., 2020; Gil-Alana et al., 2020c, 2018).

Our study contributes to an emerging strand of the literature focusing on EPU shock transmissions across countries and its economic impact. For instance, Caggiano et al. (2018) show that increases in US uncertainty affect Canadian uncertainty and lead to a temporary increase in the Canadian unemployment rate. Osei et al. (2021) provide evidence of long-run threshold cointegration and asymmetric adjustment towards the long-run equilibrium for the China-India and India-Japan EPU pairs in an M-TAR specification with nonzero threshold values; they also find a unidirectional causal relationship for the China-India, China-Japan, and India-Korea EPU pairs both in the long and short run using the spectral frequency domain causality approach. Our analysis provides fresh insights into the degree of persistence and the transmission of EPU shocks across these economies and has implications both for investors having to make risk management decisions and choose investment strategies and policymakers having to design effective macroeconomic policies.

The layout of the paper is the following. Section 2 provides a brief review of the relevant literature. Section 3 outlines the empirical methodology. Section 4 describes the data and presents the empirical results. Section 5 provides some concluding remarks.

\section{Literature review}

Economic policy uncertainty (EPU) is defined as the agents' inability to predict future economic policies as well as the consequences of policies that have already been adopted by the government. Agents often face uncertainty about the timing, content and potential effect of policy decisions. Quantifying policy uncertainty is very difficult because of its unobservable nature. Baker et al. (2016) constructed an index for EPU based on newspaper coverage frequency, the underlying idea being that a higher number of news articles about EPU reflects a higher level of uncertainty faced by agents. Subsequent papers have followed a similar approach for developing EPU indices for other countries (Arbatli et al., 2017; Cerda et al., 2016; Zalla, 2017; Hlatshwayo and Saxegaard, 2016; Kroese et al., 2015; Bhagat et al., 2013). Interestingly, an incumbent party re-election probability, derived from prediction markets, appears to be one of the key drivers of economic policy uncertainty (see Goodall et al., 2020, for the US case).

There are different strands in the literature on the role of uncertainty shocks. One of them focuses on the measurement and the macroeconomic effects of economic policy uncertainty. Proxies for uncertainty have been constructed by using measures of forecast disagreement (Bachmann et al., 2013), by relating the location of the real GDP forecast errors to the sample distribution of the forecast errors of the same variable (Rossi and Sekhposyan, 2016), by modelling the common component of the volatility of the forecast errors of several macroeconomic and financial indicators (Jurado et al., 2015; Ludvigson et al., 2017; and Carriero et al., 2018), by exploiting Bloomberg forecasts to capture agents' uncertainty surrounding current realizations of real economic activity (Scotti, 2016), and by focusing on interest rate uncertainty as in Creal and Wu (2017) and Istrefi and Mouabbi (2018), or working with Google Trends data as in Castelnuovo and Tran (2017).

Other studies have examined the impact of the EPU index constructed as in Baker et al. $(2014,2016)$ on various economic variables. Using firm-level data, Gulen and Ion (2016) found that EPU can explain up to $32 \%$ of the drop in corporate investment over the 2007-2009 time period. Luo and Zhang (2020) provided evidence that Chinese listed firms are more likely to experience stock price crashes when EPU increases; further, EPU is significantly and positively associated with aggregated stock price crash risk at the market level. Pastor and Veronesi $(2012,2013)$ developed a model in which agents learn through a Bayesian updating process about the effects of policies endogenously chosen by governments; they also showed that higher EPU is associated with higher volatility of US equities and higher correlations between them. Gourinchas and Parker (2002) and Guiso et al. (2013) showed the importance of life-cycle income uncertainty on pre-cautionary savings. Brogaard and Detzel (2015) found that increases in EPU lower equity prices by raising the discount rate on future cash flows and by affecting the risk premium. Nguyen et al. (2020) found that a higher level of EPU has a negative impact on bank credit growth and that this effect is stronger in emerging than in advanced economies. Shoag and Veuger 
(2016) showed that the cross-sectional variation in uncertainty can explain a significant percentage of unemployment fluctuations during the Great Recession.

Another strand of the literature focuses on the role of uncertainty in an open economy context. Fernández-Villaverde et al. (2011) and Born and Pfeifer (2014) find that changes in the volatility of the real interest rate at which small open emerging economies borrow affect real activity in open economies such as Argentina, Ecuador, Venezuela, and Brazil. Benigno et al. (2012) provide evidence that the volatility of US monetary policy shocks, inflation target shocks, and productivity shocks has an impact on a number of nominal and real indicators in the G7. Gourio (2013) build a two-country RBC model in which aggregate uncertainty is time-varying and countries have heterogeneous exposures to a world aggregate shock. Other studies examines the effects of uncertainty shocks on real activity as predicted by DSGE models with micro foundations. Gilchrist and Williams (2005) show that uncertainty shocks are expansionary because, in their model, they exert a negative effect on household wealth, increase the marginal utility of consumption and thus labour supply, which eventually increases output. Leduc and Liu (2016) show that a in labour market model featuring matching frictions uncertainty shocks affect have a negative effect on output.

A number of recent studies have focused on policy uncertainty linkages across countries. Klößner and Sekkel (2014) considered six developed countries and found evidence of significant uncertainty spillovers from the US and the UK to other countries. Luk et al. (2020) found large EPU spillovers from the US, Europe, mainland China, and Japan to a small open economy such as Hong Kong. Cekin et al. (2020) investigated the dependence structure of EPU in four Latin American economies (Brazil, Chile, Colombia, and Mexico) by employing vine copula modelling with various forms of tail dependence; they found significant dependencies in economic uncertainty among those countries. Using a QVAR model, Balcilar et al. (2020a, 2020b) examined EPU spillovers from the US and the EU to five Asian economies (China, Hong Kong, Japan, South Korea, and India) and found a negative impact except in China and Hong Kong. Bai et al. (2019) investigated risk contagion among major economies including the US, UK, Germany, France, Japan, and China and found strong linkages in the time domain and spillovers especially at the short-run frequency; moreover, the US appears to be the key transmitter, while the UK and China are the major spillover receivers. Osei et al. (2021) found some evidence of threshold cointegration and asymmetric adjustment for EPU when analysing the China-India, China-Japan, China-Korea, India-Japan, India-Korea, and Japan-Korea country pairs. Hansan et al. (2020) concluded that higher EPU connectedness between countries increases fear connectedness between their stock markets. Prüser and Schlösser (2020) used a TVP-FAVAR model with hierarchical priors on the hyperparameters to investigate the effect of EPU on a wide range of macroeconomic variables for eleven European Monetary Union (EMU) countries; their results indicate that EPU shocks are transmitted through various channels, namely the real option, the precautionary savings and financial channel. Caggiano et al. (2020), as already mentioned, estimated a nonlinear VAR to quantify the impact of EPU shocks originating in the US on the Canadian unemployment rate in booms and busts and found strong evidence of asymmetric spillover effects.

As for the effects of specific types of uncertainty, Baker et al. (2016) found that tax policy uncertainty is the largest source of policy uncertainty in the US. Kydland and Zarazaga (2016) showed that uncertainty about fiscal policy (and, more specifically, tax policy) accounts for the weaker than expected recovery of the US economy after the 2007-2008 crisis. Sinha (2016) reported that an increase in interest rate uncertainty leads to lower output, while Husted et al. (2018) found that higher monetary policy uncertainty in the US increases interest rates and yield spreads and lowers output and inflation. Aghion et al. (2009) provided evidence that real exchange rate volatility can affect output growth significantly, while Aguiar (2005) found that, after the Mexican Peso devaluation, the balance sheet effect outweighed the potential benefits for exports. Finally, Kane (2000) provided evidence about the connection between capital outflows, banking insolvency and silent runs during the Asian crisis.

\section{Methodology}

The methodology used in the paper is based on the concept of fractional integration initially introduced by Granger (1980). He showed that many economic aggregates display estimated spectrums with a large value at the zero frequency, which suggests that first differences of these series should be taken. However, once they are first differenced, the estimated spectrum shows values close to zero at the smallest (zero) frequency, which implies over-differentiation. This observation led to the development of fractional integration or I(d) models with $0<\mathrm{d}<1$.

These processes became popular in the econometrics literature in the late 1990s. Nelson and Plosser (1982) had examined fourteen macroeconomics series and found that models with unit roots or stochastic trends were more appropriate than deterministic ones; however, using an extended sample, Gil-Alana and Robinson (1997) concluded that all of them except one displayed orders of integration in the interval $(0,1)$ that are significantly different from 1 . Since then, $\mathrm{I}(\mathrm{d})$ models have been widely employed in the literature (see, e.g., Banerjee and Urga, 2005; Mayoral, 2006; Gil-Alana and Moreno, 2012; Abbritti et al., 2016; Baillie et al., 2019; etc.).

Fractional cointegration is a natural extension of fractional integration to the multivariate case. Cointegration was first introduced in the seminal paper by Engle and Granger (1987), who argued that two or more series are cointegrated if they are non-stationary and integrated of order d, i.e., I(d), but there exists at least one linear combination of them which is integrated of order $d-b$, with $b>0$. Although this definition held for any real values $d$ and $b$, all the empirical applications based on this approach assumed integer degrees of differentiation, namely $\mathrm{d}=\mathrm{b}=1$. Subsequently, Johansen $(1988,1991,1995)$ introduced the LR and trace test statistics for cointegration in a multivariate framework. The extension to the fractional case was first implemented by Cheung and Lai (1993) and Gil-Alana (2003) having been introduced in a series of papers by Maarinucci and Robinson (2001), Robinson and Yajima (2002); Robinson and Hualde (2003), Hualde and Robinson (2007), etc. Later on, Johansen and Nielsen (2010, 2012) extended the CVAR model (Johansen, 1991; Johansen and Juselius, 1994) to the fractional case (fractional CVAR, FVAR model). 


\section{Data and empirical results}

\subsection{Data description}

Monthly data for the EPU index constructed by Baker et al. (2016) have been downloaded from the website www. policyuncertainty.com for the six countries with the longest data span (Canada, France, Japan, USA, Ireland, and Sweden), namely from January 1985 to October 2019. This index has already been used by several researchers (for example, He and Niu, 2018, and Ko and Lee, 2015) because, as argued by Istiak and Serletis (2018), it has four advantages over other uncertainty measures: (i) it incorporates past movements in policy-related economic uncertainty, (ii) it is available for all the big economies (see www. policyuncertainty.com), (iii) it reflects the true nature of uncertainty for the whole economy, and (iv) it explains the cross-sectional patterns in some economic variables.

\subsection{Univariate analysis}

As a first step, we carry out the univariate analysis using the following model:

$$
y_{t}=\alpha+\beta t+x_{t}, \quad(1-L)^{d} x_{t}=u_{t} \quad t=1,2, \ldots,
$$

where $y_{t}$ stands for the observed time series (in logs); $\alpha$ and $\beta$ are the coefficients on the intercept and the linear time trend; $d$ is a real value and $u_{t}$ is assumed to be $I(0)$. We obtain estimates of the parameter $d$ from three different specifications: i) when $\alpha$ and $\beta$ are assumed to be 0 , i.e. no deterministic terms are included in the regression model (1), ii) with $\beta=0$, that is, allowing for an intercept, and iii) estimating $\alpha$ and $\beta$ from the data and therefore allowing for both an intercept and a linear time trend; Further, the disturbance term $\mathrm{u}_{\mathrm{t}}$, is assumed to follow a white noise process (in Table 1) or, alternatively, to be autocorrelated (in Table 2) as in the nonparametric spectral approach proposed by Bloomfield (1973). In both cases we select our preferred model on the basis of the significance of the regressors according to their t-statistics.

It can be seen in Table 1 that in the cases of Canada, France and Ireland a time trend is required, its coefficient being positive and significant, while an intercept is sufficient in the remaining three cases, namely Japan, Sweden and the US. All estimated values of $d$ are between 0 and 1 (specifically, they range between 0.33 (Ireland) and 0.65 (Japan)) and their confidence intervals exclude the case of $\mathrm{d}=1$; this implies that the series, though exhibiting long memory, are mean-reverting, with shocks having transitory effects. Note that for Canada and Japan the confidence intervals do not include values below 0.5 , which implies that the null of stationarity is rejected in these two cases. When allowing for autocorrelation in the residuals (in Table 2) the time trend coefficient is significant in the cases of Canada, France and US, again with a positive coefficient, and the estimates of $d$ are once more in the interval $(0,1)$, ranging from 0.40 (US) to 0.56 (France), which again implies long memory and mean-reverting behaviour. In this case, we find support of the hypothesis of stationarity only for Ireland with values of $d$ strictly below 0.5 . In all the other cases, the values are on the borderline between stationarity and nonstationarity.

\subsection{Structural break tests}

Next, we test for structural breaks, since high levels of persistence could be the consequence of breaks which have not been taken into account (Diebold and Inoue, 2001; Granger and Hyung, 2004; etc.); specifically, we carry out the Bai and Perron (2003) and Gil-Alana (2008) tests, the latter being an extension of the former to the fractional case. The detected breaks are the same in both cases (see Table 3) and can be related to some well-known economic developments. For instance, the first break in Canada can be linked to the economic growth slowdown caused by events such as the SARS outbreak, the mid-August power blackout and the war in Iraq, and Hurricane Juan in Nova Scotia, whilst the second and third breaks broadly coincide with the start of the recession following the global financial crisis (GFC) and the time by which the Canadian economy had essentially stabilised. In France the first one corresponds to the period of liberalisation under Jacques Chirac, the second to a period when the country was struggling to cope with falling investment, rising budget deficits and high unemployment, and the third and fourth one to the economy slump caused by the GFC and then the recovery. In Ireland the first break coincides with the 'Celtic Tiger' phase when a high FDI rate, a low corporate tax rate, better economic management and a new 'social partnership' approach to industrial relations led to much higher economic growth, the second to the global post-Dot Com economic slowdown, and the third to the first impact of the GFC. In Japan the first break reflects the

Table 1

Estimated coefficients of the parameters in a model with white noise errors.

\begin{tabular}{llll}
\hline Country & No terms & Intercept $(\alpha)$ & Intercept and Linear Time Trend $(\beta)$ \\
\hline CANADA & $0.59(0.53,0.68)$ & $4.2115(18.93)$ & $0.0035(2.25)$ \\
FRANCE & $0.47(0.42,0.53)$ & $4.2007(20.60)$ & $0.0033(3.20)$ \\
IRELAND & $0.33(0.29,0.39)$ & $4.1979(31.81)$ & $0.0018(3.31)$ \\
JAPAN & $0.65(0.58,0.75)$ & $4.3388(30.16)$ & - \\
SWEDEN & $0.46(0.41,0.53)$ & $4.6346(65.08)$ & - \\
US & $0.54(0.47,0.64)$ & $4.6219(29.54)$ & - \\
\hline
\end{tabular}

Notes: In parenthesis, in the second column, the $95 \%$ confidence band for the values of $d$; in column 3 and 4, the corresponding t-values. 
Table 2

Estimated coefficients of the parameters in a model with autocorrelated errors.

\begin{tabular}{llll}
\hline Country & No terms & Intercept $(\alpha)$ & Intercept and Linear Time Trend $(\beta)$ \\
\hline CANADA & $0.54(0.45,0.66)$ & $4.2027(20.61)$ & $0.0034(2.80)$ \\
FRANCE & $0.56(0.47,0.65)$ & $4.2241(17.04)$ & $0.0033(2.11)$ \\
IRELAND & $0.42(0.34,0.50)$ & $4.5514(21.91)$ & - \\
JAPAN & $0.53(0.43,0.66)$ & $4.4031(39.87)$ & - \\
SWEDEN & $0.45(0.38,0.53)$ & $4.4965(37.63)$ & $0.0011(2.11)$ \\
US & $0.40(0.31,0.53)$ & & - \\
\hline
\end{tabular}

Notes: In parenthesis, in the second column, the $95 \%$ confidence band for the values of d; in column 3 and 4 , the corresponding t-values.

Table 3

Bai and Perron's (2003) \& Gil-Alana's (2008) tests for multiple structural breaks.

\begin{tabular}{lll}
\hline Country & N. of breaks & Break dates \\
\hline CANADA & 3 & $2003 \mathrm{~m} 7 ; 2008 \mathrm{~m} 9 ; 2014 \mathrm{~m} 11$ \\
FRANCE & 4 & $1997 \mathrm{~m} 2 ; 2002 \mathrm{~m} 3 ; 2007 \mathrm{~m} 8 ; 2012 \mathrm{~m} 9$ \\
IRELAND & 3 & $1994 \mathrm{~m} 10 ; 2001 \mathrm{~m} 11 ; 2007 \mathrm{~m} 10$ \\
JAPAN & 5 & $1992 \mathrm{~m} 4 ; 1997 \mathrm{~m} 8 ; 2003 \mathrm{~m} 7 ; 2008 \mathrm{~m} 6 ; 2013 \mathrm{~m} 5$ \\
SWEDEN & 3 & $1998 \mathrm{~m} 11 ; 2003 \mathrm{~m} 10 ; 2010 \mathrm{~m} 5$ \\
US & 4 & $1993 \mathrm{~m} 9 ; 1998 \mathrm{~m} 8 ; 2003 \mathrm{~m} 10 ; 2008 \mathrm{~m} 9$ \\
\hline
\end{tabular}

beginning of the deflation period and the second a further worsening of the economic situation, whilst the third is related to the first significant impact of quantitative easing, and the last two to the slump brought about by the GFC and the following rebound. In Sweden the first is linked to the negative impact of the 'bridging policy' aiming to combine capitalism with a generous welfare state, the second to a new positive trend in the economy, and the third to the first signs of recovery after the hit of the GFC. Finally, in the US the first break broadly coincides with the beginning of the Dot Com boom, the second to some initial adjustments in the stock market when it started to become apparent that a bubble in stock valuations had occurred, and the third to the severe impact of the collapse of Lehman Brothers and other financial institutions.

Table 4 displays the estimated values of $\mathrm{d}$ for each subsample and each series under the assumption of autocorrelated errors (similar

Table 4

Estimated values of $\mathrm{d}$ under the assumption of autocorrelated errors.

\begin{tabular}{|c|c|c|c|c|}
\hline Country & & No terms & An intercept & An Intercept and a Linear Time Trend \\
\hline \multirow{5}{*}{ LCAN } & 1987M1 - 2003M6 & $0.79(0.71,0.89)$ & $0.54(0.45,0.67)$ & $0.55(0.45,0.67)$ \\
\hline & 2003M7 - 2008M8 & $0.98(0.81,1.23)$ & $0.45(0.27,0.75)$ & $0.45(0.26,0.76)$ \\
\hline & 2008M9 - 2014M10 & $0.88(0.72,1.10)$ & $0.69(0.53,0.89)$ & $0.70(0.56,0.89)$ \\
\hline & 20014M11- 2019M10 & $0.90(0.74,1.12)$ & $0.39(0.28,0.56)$ & $0.21(0.00,0.50)$ \\
\hline & 1987M1-2003M6 & & & \\
\hline \multirow{5}{*}{ LFRA } & 1987M1 - 1997M1 & $0.80(0.70,0.93)$ & $0.34(0.24,0.48)$ & $0.34(0.23,0.48)$ \\
\hline & 1997M2 - 2002M2 & $0.74(0.60,0.94)$ & $0.36(0.25,0.51)$ & $0.36(0.25,0.51)$ \\
\hline & 2002M3 - 2007M7 & $0.81(0.67,0.99)$ & $0.38(0.24,0.62)$ & $0.32(0.12,0.61)$ \\
\hline & 2007M8 - 2012M8 & $0.88(0.69,1.17)$ & $0.39(0.28,0.55)$ & $0.24(0.05,0.48)$ \\
\hline & 2012M9 - 2019M10 & $0.90(0.77,1.09)$ & $0.42(0.29,0.61)$ & $0.42(0.27,0.61)$ \\
\hline \multirow{4}{*}{ LIRE } & 1987M1 - 1994M9 & $0.64(0.50,0.81)$ & $0.14(0.03,0.30)$ & $0.09(-0.05,0.28)$ \\
\hline & 1994M10 - 2001M10 & $0.61(0.46,0.79)$ & $-0.07(-0.20,0.12)$ & $-0.09(-0.23,0.11)$ \\
\hline & 2001M11 - 2007M9 & $0.68(0.54,0.85)$ & $0.10(0.01,0.23)$ & $-0.06(-0.19,0.12)$ \\
\hline & 20007M10- 2019M10 & $0.69(0.61,0.79)$ & $0.08(-0.02,0.22)$ & $0.07(-0.04,0.21)$ \\
\hline \multirow{6}{*}{ LJAP } & 1987M1 - 1992M3 & $0.98(0.80,1.23)$ & $0.55(0.34,0.93)$ & $0.54(0.31,0.94)$ \\
\hline & 1992M4 - 1997M7 & $0.96(0.80,1.24)$ & $0.48(0.28,0.74)$ & $0.48(0.28,0.74)$ \\
\hline & 1997M8 - 2003M6 & $0.94(0.81,1.13)$ & $0.72(0.55,0.98)$ & $0.72(0.53,0.98)$ \\
\hline & 2003M7 - 2008M5 & $0.94(0.77,1.19)$ & $0.45(0.34,0.62)$ & $0.43(0.31,0.61)$ \\
\hline & 2008M6 - 2013M4 & $0.93(0.77,1.16)$ & $0.41(0.16,0.78)$ & $0.40(0.15,0.78)$ \\
\hline & 2013M5 - 2019M10 & $0.91(0.77,1.12)$ & $0.71(0.53,1.00)$ & $0.71(0.52,1.00)$ \\
\hline \multirow{4}{*}{ LSWE } & 1987M1 - 1998M10 & $0.90(0.81,1.02)$ & $0.34(0.24,0.49)$ & $0.35(0.25,0.49)$ \\
\hline & 1998M11 - 2003M9 & $0.91(0.75,1.14)$ & $0.49(0.34,0.80)$ & $0.52(0.36,0.80)$ \\
\hline & 2003M10 - 2010M5 & $0.94(0.79,1.13)$ & $0.39(0.25,0.60)$ & $0.36(0.17,0.59)$ \\
\hline & 2010M6 - 2019M10 & $0.89(0.75,1.09)$ & $0.19(0.04,0.41)$ & $0.15(-0.05,0.40)$ \\
\hline \multirow{5}{*}{ LUS } & 1987M1 - 1993M8 & $0.87(0.74,1.06)$ & $0.45(0.24,0.75)$ & $0.44(0.23,0.74)$ \\
\hline & 1993M9 - 1998M7 & $0.96(0.79,1.26)$ & $0.30(0.09,0.66)$ & $0.30(0.06,0.66)$ \\
\hline & 1998M8 - 2003M9 & $0.93(0.71,1.22)$ & $0.72(0.52,1.02)$ & $0.72(0.50,1.02)$ \\
\hline & 2003M10 - 2008M8 & $0.86(0.72,1.07)$ & $0.48(0.33,0.69)$ & $0.47(0.32,0.69)$ \\
\hline & 2008M9 - 2019M10 & $0.85(0.75,0.99)$ & $0.44(0.33,0.62)$ & $0.45(0.33,0.64)$ \\
\hline
\end{tabular}

Notes: In bold the estimates from the specification selected on the basis of the statistical significance of the deterministic terms for each country. In parenthesis, the $95 \%$ confidence band for the values of $d$. 
results, not reported for brevity's sake, were obtained in the case of white noise disturbances). In most cases they are significantly positive, which indicates the presence of long memory. Evidence of short memory, i.e., $d=0$, is only found in the last subsample for Canada and the last three subsamples for Ireland.

\subsection{Fractional cointegration analysis}

Next, we examine the possible existence of a long-run equilibrium relationship between the series of interest by carrying out fractional cointegration tests. This requires establishing in the first instance whether the individual series have the same degree of integration.

Table 5 summarises the estimated values of $d$ for each series using Robinson's (1994) parametric approach. Table 6 shows instead the estimates obtained applying a semi-parametric method which does not require any assumption about the I(0) error term; in particular, we use a "local" Whittle approach with the frequencies degenerating to zero as in Robinson (1995); this has the advantage of being simple and requiring a single bandwidth parameter, whilst more recent methods (see, e.g., Velasco, 1999; Phillips and Shimotsu, 2005; Abadir et al., 2007) require additional ones, with the estimates of d generally being very sensitive to those. It can be seen that the semi-parametric estimates are much higher than the parametric ones, in all cases exceeding 0.5, which implies non-stationary behaviour.

Next we test for the homogeneity in the orders of integration across countries by employing the Robinson and Yajima's (2002) approach. The results are displayed in Table 7: the null of equal orders of integration cannot be rejected in any case. The same conclusion is reached using Hualde's (2003) approach (these results are not reported to save space).

To test for cointegration we use first Engle and Granger (1987)'s approach; this involves testing the order of integration of the estimated residuals from the OLS regression of one variable against another (see Gil-Alana, 2003). The estimated values of $d$ for the three model specifications are reported in Tables 8 and 9 for the two cases of white noise and autocorrelated errors respectively, and provide very little evidence of a lower degree of integration compared to the individual series. The values in bold are those corresponding in each case to our preferred specification (which is selected on the basis of the statistical significance of the other coefficients) and are also reported in Table 10 which summarises the cointegration results.

Next, we test the null hypothesis of no cointegration versus the alternative of fractional cointegration by carrying out the Hausman test proposed by Marinucci and Robinson (2001), who tested that

$$
\mathrm{H}_{\mathrm{is}}=8 s\left(\widehat{d}_{*}-\widehat{d}_{i}\right)^{2} \rightarrow d \chi_{1}^{2} \text { as } \frac{1}{s}+\frac{s}{T} \rightarrow 0
$$

where $\mathrm{i}=\mathrm{x}, \mathrm{y} ; \mathrm{s}<[\mathrm{T} / 2]$ is another bandwidth parameter similar to $\mathrm{m}$ above, and $\widehat{d}_{*}$ is a restricted estimate of $\mathrm{d}$ obtained from the bivariate representation of the two series under the assumption that $d_{x}=d_{y}$. More precisely:

$$
\widehat{\mathrm{d}}_{*}=-\frac{\sum_{\mathrm{j}=1}^{\mathrm{S}} 1_{2}^{\mathrm{T}} \widehat{\Omega}^{-1} Y_{j} v_{j}}{21_{2}^{\mathrm{T}} \widehat{\Omega}^{-1} \sum_{j=1}^{S} v_{j}^{2}},
$$

where $\mathrm{Yj}=\left[\log \mathrm{I}_{\mathrm{xx}}(\lambda \mathrm{j}), \log \mathrm{I}_{\mathrm{yy}}(\lambda \mathrm{j})\right]^{\mathrm{T}}$ and $\mathrm{v}_{\mathrm{j}}=\log j-\frac{1}{s} \sum_{j=1}^{S} \log j$ and $\widehat{\Omega}$ is a consistent estimate of the limiting variance matrix of $2 s^{1 / 2}(\hat{d}-d)$

The estimates of $\mathrm{d}$ * from the joint representation of the two series for a range of bandwidth parameters from 10 to 15 are reported in Table 11; they are required for the Hausman test in a semi-parametric context.

Tables 12 and 13 display the Hausman test results for testing the null of no cointegration against the alternative of cointegration. Specifically, Table 12 presents the results based on Robinson's (1994) parametric approach, and Table 13 those obtained using the "local" Whittle semi-parametric approach. In the former case the only evidence of cointegration is obtained for Canada versus US for two of the bandwidth parameters, and for Ireland versus US for all bandwidths. In the latter case there is some evidence of cointegration only for the cases of France/Ireland, Ireland/US, Japan/Sweden and Japan/US.

To sum up, the fractional cointegration analysis provides relatively little evidence of EPU cross-country linkages. It is interesting

Table 5

Estimates of d on the parent series using Robinson (1994).

\begin{tabular}{lll}
\hline Series & No autocorrelation & With autocorrelation \\
\hline CANADA & $0.59(0.53,0.68)$ & $0.54(0.45,0.66)$ \\
FRANCE & $0.47(0.42,0.53)$ & $0.56(0.47,0.65)$ \\
IRELAND & $0.33(0.29,0.39)$ & $0.42(0.34,0.50)$ \\
JAPAN & $0.65(0.58,0.75)$ & $0.53(0.43,0.66)$ \\
SWEDEN & $0.46(0.41,0.53)$ & $0.45(0.38,0.53)$ \\
US & $0.54(0.47,0.64)$ & $0.40(0.31,0.53)$ \\
\hline
\end{tabular}

Notes: In parenthesis, the $95 \%$ confidence band for the values of $\mathrm{d}$. 
Table 6

Estimates of $d$ using a semi-parametric approach.

\begin{tabular}{lllll}
\hline Series / $\mathrm{m}$ & $11 \approx \mathrm{T}^{0.4}$ & $18 \approx \mathrm{T}^{0.5}-1$ & $19 \approx \mathrm{T}^{0.5}$ & $20 \approx \mathrm{T}^{0.5}+1$ \\
\hline CANADA & 0.692 & 0.706 & 0.714 & 0.731 \\
FRANCE & 0.756 & 0.722 & 0.731 & 0.600 \\
IRELAND & 0.891 & 0.746 & 0.758 & 0.634 \\
JAPAN & 0.560 & 0.521 & 0.564 & 0.796 \\
SWEDEN & 0.843 & 0.748 & 0.749 & 0.618 \\
US & 0.535 & 0.640 & 0.693 & 0.723 \\
\hline
\end{tabular}

Table 7

Robinson and Yajima's (2002) tests for homogeneity in the integration order.

\begin{tabular}{|c|c|c|c|c|c|}
\hline & FRANCE & IRELAND & JAPAN & SWEDEN & US \\
\hline CANADA & -0.170 & -0.440 & 1.499 & -0.350 & 0.209 \\
\hline FRANCE & - & -0.270 & 1.669 & -0.180 & 0.379 \\
\hline IRELAND & - & - & 1.940 & 0.090 & 0.649 \\
\hline JAPAN & - & - & - & -1.850 & -1.293 \\
\hline SWEDEN & - & - & - & - & 0.559 \\
\hline US & - & - & - & - & - \\
\hline
\end{tabular}

Table 8

Fractional cointegration using Engle and Granger (1987) (Gil-Alana, 2003) under the assumption of white noise errors.

\begin{tabular}{|c|c|c|c|}
\hline Country & No terms & An intercept & An Intercept and a Linear Time Trend \\
\hline LCAN / LFRA & $0.41(0.35,0.47)$ & $0.41(0.35,0.47)$ & $0.41(0.35,0.47)$ \\
\hline LCAN / LIRE & $0.40(0.35,0.46)$ & $0.40(0.35,0.46)$ & $0.39(0.34,0.46)$ \\
\hline LCAN / LJAP & $0.53(0.48,0.60)$ & $0.53(0.48,0.60)$ & $0.52(0.47,0.60)$ \\
\hline LCAN / LSWE & $0.52(0.46,0.59)$ & $0.50(0.45,0.57)$ & $0.48(0.41,0.56)$ \\
\hline LCAN / LUS & $0.40(0.36,0.45)$ & $0.39(0.35,0.45)$ & $0.38(0.34,0.44)$ \\
\hline LFRA / LIRE & $0.33(0.28,0.38)$ & $0.32(0.28,0.37)$ & $0.28(0.24,0.34)$ \\
\hline LFRA / LJAP & $0.49(0.43,0.54)$ & $0.48(0.44,0.53)$ & $0.47(0.42,0.52)$ \\
\hline LFRA / LSWE & $0.49(0.45,0.55)$ & $0.48(0.44,0.53)$ & $0.45(0.40,0.52)$ \\
\hline LFRA / LUS & $0.44(0.40,0.49)$ & $0.43(0.34,0.49)$ & $0.42(0.37,0.48)$ \\
\hline LIRE / LJAP & $0.26(0.22,0.30)$ & $0.26(0.22,0.30)$ & $0.23(0.19,0.28)$ \\
\hline LIRE / LSWE & $0.26(0.22,0.31)$ & $0.26(0.22,0.31)$ & $0.21(0.17,0.26)$ \\
\hline LIRE / LUS & $0.18(0.14,0.23)$ & $0.18(0.14,0.23)$ & $0.15(0.08,0.21)$ \\
\hline LJAP / LSWE & $0.65(0.58,0.74)$ & $0.65(0.57,0.74)$ & $0.65(0.57,0.74)$ \\
\hline LJAP / LUS & $\begin{array}{l}0.54(0.47,0.61) \\
3\end{array}$ & $0.53(0.47,0.61)$ & $0.53(0.47,0.61)$ \\
\hline LSWE / LUS & $0.44(0.39,0.51)$ & $0.44(0.39,0.50)$ & $0.43(0.38,0.49)$ \\
\hline
\end{tabular}

Notes: In bold the estimates from the specification selected on the basis of the statistical significance of the deterministic terms for each pair of countries. In parenthesis, the $95 \%$ confidence band for the values of $d$.

that the few cases with significant long-run spillovers typically involve a larger and a smaller economy (France/Ireland, Ireland/US, Japan/Sweden), which confirms our prior that smaller open economies with perfect capital mobility and a highly developed financial sector should be more vulnerable to international uncertainty shocks, and is consistent with previous findings concerning spillovers from some of the biggest economies in the world to Hong Kong (see Luk et al., 2020) and from the US to Canada(see Caggiano et al., 2020). This implies fewer portfolio diversification opportunities for investors and a lower degree of effectiveness of domestic policies.

\section{Conclusions}

It is well known that uncertainty in its various forms affects the behaviour of economic agents (consumers and/or firms). One specific type of uncertainty whose role has been analysed extensively in recent years is EPU. Most studies have used the index constructed by Baker et al. (2016), whose advantages are apparent, and investigated its impact on the economy as a whole and the financial sector in particular. However, its statistical properties and possible cross-country linkages have not been considered. The present paper aims to fill this gap by providing new evidence on the stochastic behaviour of EPU in six of the biggest economies in terms of GDP for which long runs of data are available (Canada, France, Japan, US, Ireland, and Sweden); in particular, it uses fractional integration methods to shed light on its degree of persistence, and also carries out appropriate break tests. In addition, the possible co-movement of this index between countries is examined by applying a fractional cointegration method which tests for the 
Table 9

Fractional cointegration using Engle and Granger (1987) (Gil-Alana, 2003) under the assumption of autocorrelated errors.

\begin{tabular}{|c|c|c|c|}
\hline Country & No terms & An intercept & An Intercept and a Linear Time Trend \\
\hline LCAN / LFRA & $0.44(0.38,0.63)$ & $0.49(0.38,0.63)$ & $0.50(0.40,0.63)$ \\
\hline LCAN / LIRE & $0.46(0.37,0.56)$ & $0.44(0.36,0.56)$ & $0.45(0.35,0.57)$ \\
\hline LCAN / LJAP & $0.55(0.46,0.65)$ & $0.45(0.47,0.65)$ & $0.54(0.45,0.66)$ \\
\hline LCAN / LSWE & $0.50(0.42,0.59)$ & $0.48(0.41,0.57)$ & $0.41(0.32,0.54)$ \\
\hline LCAN / LUS & $0.47(0.40,0.56)$ & $0.46(0.40,0.54)$ & $0.45(0.39,0.54)$ \\
\hline LFRA / LIRE & $0.43(0.36,0.50)$ & $0.41(0.35,0.48)$ & $0.38(0.30,0.48)$ \\
\hline LFRA / LJAP & $0.62(0.55,0.72)$ & $0.62(0.53,0.70)$ & $0.60(0.53,0.70)$ \\
\hline LFRA / LSWE & $0.56(0.50,0.65)$ & $0.54(0.48,0.62)$ & $0.51(0.43,0.61)$ \\
\hline LFRA / LUS & $0.52(0.46,0.60)$ & $0.51(0.44,0.60)$ & $0.49(0.43,0.59)$ \\
\hline LIRE / LJAP & $0.39(0.33,0.49)$ & $0.40(0.34,0.48)$ & $0.37(0.30,0.47)$ \\
\hline LIRE / LSWE & $0.39(0.33,0.48)$ & $0.39(0.33,0.49)$ & $0.35(0.26,0.46)$ \\
\hline \multirow[t]{2}{*}{ LIRE / LUS } & $0.25(0.19,0.33)$ & $0.25(0.19,0.34)$ & $0.21(0.13,0.32)$ \\
\hline & $0.48(0.41,0.57)$ & $0.45(0.41,0.57)$ & $0.45(0.41,0.57)$ \\
\hline LJAP / LSWE & $0.57(0.47,0.70)$ & $0.55(0.45,0.68)$ & $0.55(0.45,0.68)$ \\
\hline \multirow[t]{2}{*}{ LJAP / LUS } & $0.55(0.45,0.70)$ & $0.54(0.44,0.68)$ & $0.55(0.44,0.68)$ \\
\hline & $0.41(0 ., 0.48)$ & $0.41(0 ., 0.48)$ & $0.41(0 ., 0.48)$ \\
\hline LSWE / LUS & $0.47(0.40,0.56)$ & $0.46(0.40,0.54)$ & $0.45(0.38,0.53)$ \\
\hline
\end{tabular}

Notes: In bold the estimates from the specification selected on the basis of the statistical significance of the deterministic terms for each pair of countries. In parenthesis, the $95 \%$ confidence band for the values of $d$.

Table 10

Summary of the results in Tables 8 and 9.

\begin{tabular}{lll}
\hline Country & No autocorrelation & With autocorrelation \\
\hline LCAN / LFRA & $0.41(0.35,0.47)$ & $0.49(0.38,0.63)$ \\
LCAN / LIRE & $0.39(0.34,0.46)$ & $0.45(0.35,0.57)$ \\
LCAN / LJAP & $0.52(0.47,0.60)$ & $0.54(0.45,0.66)$ \\
LCAN / LSWE & $0.48(0.41,0.56)$ & $0.41(0.32,0.54)$ \\
LCAN / LUS & $0.38(0.34,0.44)$ & $0.45(0.39,0.54)$ \\
& & \\
LFRA / LIRE & $0.28(0.24,0.34)$ & $0.38(0.30,0.48)$ \\
LFRA / LJAP & $0.47(0.42,0.52)$ & $0.62(0.53,0.70)$ \\
LFRA / LSWE & $0.45(0.40,0.52)$ & $0.51(0.43,0.61)$ \\
LFRA / LUS & $0.42(0.37,0.48)$ & $0.49(0.43,0.59)$ \\
& & $0.49(0.43,0.59)$ \\
LIRE / LJAP & $0.23(0.19,0.28)$ & $0.40(0.34,0.48)$ \\
LIRE / LSWE & $0.21(0.17,0.26)$ & $0.35(0.26,0.46)$ \\
LIRE / LUS & $0.15(0.08,0.21)$ & $0.21(0.13,0.32)$ \\
& & \\
LJAP / LSWE & $0.65(0.57,0.74)$ & $0.55(0.45,0.68)$ \\
LJAP / LUS & $0.53(0.47,0.61)$ & $0.54(0.44,0.68)$ \\
LSWE / LUS & & \\
\hline
\end{tabular}

Notes: In parenthesis, the $95 \%$ confidence band for the values of $d$.

possible existence of a long-run equilibrium relationship linking the individual indices.

The main results can be summarised as follows. EPU is found to be in most cases a non-stationary, mean-reverting series which is characterised by long memory and also exhibits breaks. This has implications for both market participants and policy makers. Specifically, highly persistent uncertainty has a detrimental effect on investment decisions and makes the implementation of policy rules such as inflation targeting less effective. Further, there is very little evidence of cross-country linkages over the full sample. The presence of breaks would appear to suggest that sub-sample analysis might provide additional information, but in fact it would not be reliable given the small number of observations for each subsample on which it would be based and therefore it has not been carried out.

On the whole it appears that country-specific EPU is a more important factor than international connectedness in generating fear and a "wait and see" attitude in investors, both of which affect directly stock market performance and indirectly the real economy. As for policy-makers, their focus should be mainly on reducing the domestic sources of uncertainty rather than worrying about its international transmission. These findings should also be taken into account by academics, policy makers and practitioners when building models aimed at evaluating the impact of EPU on the economy, designing policy measures and developing investment strategies.

Future work will address other issues such as the presence of cyclical patterns in EPU and also apply alternative methods such as 
Table 11

Estimates of $d_{*}$ in the bivariate representation of the series.

\begin{tabular}{|c|c|c|c|c|c|}
\hline Series / m & $11 \approx \mathrm{T}^{0.4}$ & $18 \approx \mathrm{T}^{0.5}-1$ & $19 \approx \mathrm{T}^{0.5}$ & $20 \approx \mathrm{T}^{0.5}+1$ & $36 \approx \mathrm{T}^{0.6}$ \\
\hline LCAN / LFRA & 0.811 & 0.595 & 0.586 & 0.599 & 0.498 \\
\hline LCAN / LIRE & 0.800 & 0.698 & 0.715 & 0.728 & 0.659 \\
\hline LCAN / LJAP & 0.693 & 0.673 & 0.686 & 0.710 & $0.578(2)$ \\
\hline LCAN / LSWE & 0.586 & 0.513 & 0.587 & 0.634 & 0.498 \\
\hline LCAN / LUS & 0.694 & 0.763 & 0.760 & 0.719 & 0.637 \\
\hline LFRA / LIRE & 0.660 & 0.539 & 0.567 & 0.584 & 0.553 \\
\hline LFRA / LJAP & 0.706 & 0.713 & 0.724 & 0.732 & 0.649 \\
\hline LFRA / LSWE & 0.742 & 0.671 & 0.690 & 0.680 & 0.608 \\
\hline LFRA / LUS & 0.766 & 0.766 & 0.781 & 0.777 & 0.638 \\
\hline LIRE / LJAP & 0.741 & 0.731 & 0.739 & 0.771 & 0.463 \\
\hline LIRE / LSWE & 0.744 & 0.738 & 0.755 & 0.787 & 0.414 \\
\hline LIRE / LUS & 0.687 & 0.595 & 0.614 & 0.488 & 0.348 \\
\hline LJAP / LSWE & 0.307 & 0.390 & 0.353 & 0.486 & 0.862 \\
\hline LJAP / LUS & 0.319 & 0.392 & 0.427 & 0.450 & 0.471 \\
\hline LSWE / LUS & 0.633 & 0.759 & 0.762 & 0.717 & 0.594 \\
\hline
\end{tabular}

Table 12

Testing fractional cointegration with Marinucci and Robinson (2001) using the parametric approach of Robinson (1994).

\begin{tabular}{|c|c|c|c|c|c|c|}
\hline \multirow[t]{2}{*}{ series / m } & \multicolumn{3}{|c|}{ No autocorrelation } & \multicolumn{3}{|c|}{ With autocorrelation } \\
\hline & $18 \approx \mathrm{T}^{0.5}-1$ & $19 \approx \mathrm{T}^{0.5}$ & $20 \approx \mathrm{T}^{0.5}+1$ & $18 \approx \mathrm{T}^{0.5}-1$ & $19 \approx \mathrm{T}^{0.5}$ & $20 \approx \mathrm{T}^{0.5}+1$ \\
\hline \multirow{2}{*}{ LCAN / LFRA } & $\mathrm{H}_{10}: 4.66$ & $\mathrm{H}_{10}: 4.92$ & $\mathrm{H}_{10}: 5.18$ & $\mathrm{H}_{10}: 0.36$ & $\mathrm{H}_{10}: 0.38$ & $\mathrm{H}_{10}: 0.40$ \\
\hline & $\mathrm{H}_{20}: 0.51$ & $\mathrm{H}_{20}: 0.54$ & $\mathrm{H}_{20}: 0.57$ & $\mathrm{H}_{20}: 0.70$ & $\mathrm{H}_{20}: 0.74$ & $\mathrm{H}_{20}: 0.78$ \\
\hline \multirow{2}{*}{ LCAN / LIRE } & $\mathrm{H}_{10}: 5.75$ & $\mathrm{H}_{10}: 6.07$ & $\mathrm{H}_{10}: 6.39$ & $\mathrm{H}_{10}: 1.16$ & $\mathrm{H}_{10}: 1.23$ & $\mathrm{H}_{10}: 1.29$ \\
\hline & $\mathrm{H}_{20}: 0.51$ & $\mathrm{H}_{20}: 0.54$ & $\mathrm{H}_{20}: 0.57$ & $\mathrm{H}_{20}: 0.12$ & $\mathrm{H}_{20}: 0.13$ & $\mathrm{H}_{20}: 0.14$ \\
\hline \multirow{2}{*}{ LCAN / LJAP } & $\mathrm{H}_{10}: 0.70$ & $\mathrm{H}_{10}: 0.74$ & $\mathrm{H}_{10}: 0.78$ & $\mathrm{H}_{10}: 0.00$ & $\mathrm{H}_{10}: 0.01$ & $\mathrm{H}_{10}: 0.00$ \\
\hline & $\mathrm{H}_{20}: 2.43$ & $\mathrm{H}_{20}: 2.56$ & $\mathrm{H}_{20}: 2.70$ & $\mathrm{H}_{20}: 0.01$ & $\mathrm{H}_{20}: 0.01$ & $\mathrm{H}_{20}: 0.01$ \\
\hline \multirow{2}{*}{ LCAN / LSWE } & $\mathrm{H}_{10}: 1.74$ & $\mathrm{H}_{10}: 1.83$ & $\mathrm{H}_{10}: 1.93$ & $\mathrm{H}_{10}: 2.43$ & $\mathrm{H}_{10}: 2.56$ & $\mathrm{H}_{10}: 2.70$ \\
\hline & $\mathrm{H}_{20}: 0.05$ & $\mathrm{H}_{20}: 0.06$ & $\mathrm{H}_{20}: 0.06$ & $\mathrm{H}_{20}: 0.24$ & $\mathrm{H}_{20}: 0.24$ & $\mathrm{H}_{20}: 0.26$ \\
\hline \multirow{2}{*}{ LCAN / LUS } & $\mathrm{H}_{10}: 6.35$ & $\mathrm{H}_{10}: 6.70$ & $\mathrm{H}_{10}: 7.05$ & $\mathrm{H}_{10}: 1.16$ & $\mathrm{H}_{10}: 1.23$ & $\mathrm{H}_{10}: 1.29$ \\
\hline & $\mathrm{H}_{20}: 3.68$ & $\mathrm{H}_{20}: 3.89$ & $\mathrm{H}_{20}: 4.09$ & $\mathrm{H}_{20}: 0.36$ & $\mathrm{H}_{20}: 0.37$ & $\mathrm{H}_{20}: 0.40$ \\
\hline \multirow{2}{*}{ LFRA / LIRE } & $\mathrm{H}_{10}: 5.19$ & $\mathrm{H}_{10}: 5.48$ & $\mathrm{H}_{10}: 5.77$ & $\mathrm{H}_{10}: 4.66$ & $\mathrm{H}_{10}: 4.92$ & $\mathrm{H}_{10}: 5.18$ \\
\hline & $\mathrm{H}_{20}: 0.36$ & $\mathrm{H}_{20}: 0.38$ & $\mathrm{H}_{20}: 0.40$ & $\mathrm{H}_{20}: 0.23$ & $\mathrm{H}_{20}: 0.24$ & $\mathrm{H}_{20}: 0.26$ \\
\hline \multirow{2}{*}{ LFRA / LJAP } & $\mathrm{H}_{10}: 0.00$ & $\mathrm{H}_{10}: 0.00$ & $\mathrm{H}_{10}: 0.00$ & $\mathrm{H}_{10}: 0.51$ & $\mathrm{H}_{10}: 0.54$ & $\mathrm{H}_{10}: 0.57$ \\
\hline & $\mathrm{H}_{20}: 4.66$ & $\mathrm{H}_{20}: 4.92$ & $\mathrm{H}_{20}: 5.18$ & $\mathrm{H}_{20}: 1.16$ & $\mathrm{H}_{20}: 1.23$ & $\mathrm{H}_{20}: 1.29$ \\
\hline \multirow{2}{*}{ LFRA / LSWE } & $\mathrm{H}_{10}: 0.05$ & $\mathrm{H}_{10}: 0.06$ & $\mathrm{H}_{10}: 0.06$ & $\mathrm{H}_{10}: 0.36$ & $\mathrm{H}_{10}: 0.38$ & $\mathrm{H}_{10}: 0.40$ \\
\hline & $\mathrm{H}_{20}: 0.01$ & $\mathrm{H}_{20}: 0.01$ & $\mathrm{H}_{20}: 0.01$ & $\mathrm{H}_{20}: 0.51$ & $\mathrm{H}_{20}: 0.54$ & $\mathrm{H}_{20}: 0.57$ \\
\hline \multirow{2}{*}{ LFRA / LUS } & $\mathrm{H}_{10}: 0.36$ & $\mathrm{H}_{10}: 0.38$ & $\mathrm{H}_{10}: 0.40$ & $\mathrm{H}_{10}: 0.70$ & $\mathrm{H}_{10}: 0.74$ & $\mathrm{H}_{10}: 0.78$ \\
\hline & $\mathrm{H}_{20}: 2.07$ & $\mathrm{H}_{20}: 2.18$ & $\mathrm{H}_{20}: 2.30$ & $\mathrm{H}_{20}: 1.16$ & $\mathrm{H}_{20}: 1.23$ & $\mathrm{H}_{20}: 1.29$ \\
\hline \multirow{2}{*}{ LIRE / LJAP } & $\mathrm{H}_{10}: 1.44$ & $\mathrm{H}_{10}: 1.52$ & $\mathrm{H}_{10}: 1.60$ & $\mathrm{H}_{10}: 0.05$ & $\mathrm{H}_{10}: 0.06$ & $\mathrm{H}_{10}: 0.06$ \\
\hline & $\mathrm{H}_{20}: 25.9$ & $\mathrm{H}_{20}: 26.8$ & $\mathrm{H}_{20}: 28.2$ & $\mathrm{H}_{20}: 2.43$ & $\mathrm{H}_{20}: 2.56$ & $\mathrm{H}_{20}: 2.70$ \\
\hline \multirow{2}{*}{ LIRE / LSWE } & $\mathrm{H}_{10}: 2.07$ & $\mathrm{H}_{10}: 2.18$ & $\mathrm{H}_{10}: 2.30$ & $\mathrm{H}_{10}: 0.70$ & $\mathrm{H}_{10}: 0.74$ & $\mathrm{H}_{10}: 0.78$ \\
\hline & $\mathrm{H}_{20}: 9.00$ & $\mathrm{H}_{20}: 9.50$ & $\mathrm{H}_{20}: 10.0$ & $\mathrm{H}_{20}: 1.44$ & $\mathrm{H}_{20}: 1.51$ & $\mathrm{H}_{20}: 1.60$ \\
\hline \multirow{2}{*}{ LIRE / LUS } & $\mathrm{H}_{10}: 4.66$ & $\mathrm{H}_{10}: 4.92$ & $\mathrm{H}_{10}: 5.18$ & $\mathrm{H}_{10}: 6.35$ & $\mathrm{H}_{10}: 6.70$ & $\mathrm{H}_{10}: 7.05$ \\
\hline & $\mathrm{H}_{20}: 21.9$ & $\mathrm{H}_{20}: 23.1$ & $\mathrm{H}_{20}: 24.3$ & $\mathrm{H}_{20}: 5.19$ & $\mathrm{H}_{20}: 5.48$ & $\mathrm{H}_{20}: 5.77$ \\
\hline \multirow{2}{*}{ LJAP / LSWE } & $\mathrm{H}_{10}: 0.00$ & $\mathrm{H}_{10}: 0.00$ & $\mathrm{H}_{10}: 0.00$ & $\mathrm{H}_{10}: 0.05$ & $\mathrm{H}_{10}: 0.06$ & $\mathrm{H}_{10}: 0.06$ \\
\hline & $\mathrm{H}_{20}: 5.19$ & $\mathrm{H}_{20}: 5.48$ & $\mathrm{H}_{20}: 5.77$ & $\mathrm{H}_{20}: 1.44$ & $\mathrm{H}_{20}: 1.52$ & $\mathrm{H}_{20}: 1.60$ \\
\hline \multirow{2}{*}{ LJAP / LUS } & $\mathrm{H}_{10}: 2.07$ & $\mathrm{H}_{10}: 2.18$ & $\mathrm{H}_{10}: 2.30$ & $\mathrm{H}_{10}: 0.01$ & $\mathrm{H}_{10}: 0.01$ & $\mathrm{H}_{10}: 0.01$ \\
\hline & $\mathrm{H}_{20}: 0.01$ & $\mathrm{H}_{20}: 0.01$ & $\mathrm{H}_{20}: 0.01$ & $\mathrm{H}_{20}: 2.82$ & $\mathrm{H}_{20}: 2.97$ & $\mathrm{H}_{20}: 3.13$ \\
\hline \multirow{2}{*}{ LSWE / LUS } & $\mathrm{H}_{10}: 0.05$ & $\mathrm{H}_{10}: 0.06$ & $\mathrm{H}_{10}: 0.06$ & $\mathrm{H}_{10}: 0.01$ & $\mathrm{H}_{10}: 0.01$ & $\mathrm{H}_{10}: 0.01$ \\
\hline & $\mathrm{H}_{20}: 1.44$ & $\mathrm{H}_{20}: 1.52$ & $\mathrm{H}_{20}: 1.60$ & $\mathrm{H}_{20}: 0.51$ & $\mathrm{H}_{20}: 0.54$ & $\mathrm{H}_{20}: 0.57$ \\
\hline
\end{tabular}

$\chi_{1}^{2}(5 \%)=3.84$. Bold indicates rejection of the null hypothesis of no cointegration at the $5 \%$ level. 
Table 13

Testing fractional cointegration with Marinucci and Robinson (2001) using the semiparametric Whittle approach.

\begin{tabular}{|c|c|c|c|c|c|}
\hline Series / m & $11 \approx \mathrm{T}^{0.4}$ & $18 \approx \mathrm{T}^{0.5}-1$ & $19 \approx \mathrm{T}^{0.5}$ & $20 \approx \mathrm{T}^{0.5}+1$ & $36 \approx \mathrm{T}^{0.6}$ \\
\hline \multirow{2}{*}{ LCAN / LFRA } & $\mathrm{H}_{10}: 1.24$ & $\mathrm{H}_{10}: 1.08$ & $\mathrm{H}_{10}: 2.49$ & $\mathrm{H}_{10}: 2.78$ & $\mathrm{H}_{10}: 2.99$ \\
\hline & $\mathrm{H}_{20}: 0.26$ & $\mathrm{H}_{20}: 1.41$ & $\mathrm{H}_{20}: 3.19$ & $\mathrm{H}_{20}: 3.13$ & $\mathrm{H}_{20}: 5.32$ \\
\hline \multirow{2}{*}{ LCAN / LIRE } & $\mathrm{H}_{10}: 1.02$ & $\mathrm{H}_{10}: 0.05$ & $\mathrm{H}_{10}: 0.01$ & $\mathrm{H}_{10}: 0.01$ & $\mathrm{H}_{10}: 1.00$ \\
\hline & $\mathrm{H}_{20}: 0.72$ & $\mathrm{H}_{20}: 0.20$ & $\mathrm{H}_{20}: 0.28$ & $\mathrm{H}_{20}: 0.73$ & $\mathrm{H}_{20}: 6.47$ \\
\hline \multirow{2}{*}{ LCAN / LJAP } & $\mathrm{H}_{10}: 0.08$ & $\mathrm{H}_{10}: 0.09$ & $\mathrm{H}_{10}: 0.11$ & $\mathrm{H}_{10}: 0.07$ & $\mathrm{H}_{10}: 0.14$ \\
\hline & $\mathrm{H}_{20}: 1.55$ & $\mathrm{H}_{20}: 2.03$ & $\mathrm{H}_{20}: 2.26$ & $\mathrm{H}_{20}: 1.35$ & $\mathrm{H}_{20}: 21.15$ \\
\hline \multirow{2}{*}{ LCAN / LSWE } & $\mathrm{H}_{10}: 0.98$ & $\mathrm{H}_{10}: 3.27$ & $\mathrm{H}_{10}: 2.45$ & $\mathrm{H}_{10}: 1.50$ & $\mathrm{H}_{10}: 2.99$ \\
\hline & $\mathrm{H}_{20}: 5.81$ & $\mathrm{H}_{20}: 4.85$ & $\mathrm{H}_{20}: 3.98$ & $\mathrm{H}_{20}: 1.26$ & $\mathrm{H}_{20}: 1.49$ \\
\hline \multirow{4}{*}{ LCAN / LUS } & $\mathrm{H}_{10}: 0.03$ & $\mathrm{H}_{10}: 0.31$ & $\mathrm{H}_{10}: 0.32$ & $\mathrm{H}_{10}: 0.02$ & $\mathrm{H}_{10}: 0.39$ \\
\hline & $\mathrm{H}_{20}: 2.22$ & $\mathrm{H}_{20}: 1.45$ & $\mathrm{H}_{20}: 0.68$ & $\mathrm{H}_{20}: 0.04$ & $\mathrm{H}_{20}: 8.03$ \\
\hline & $\mathrm{H}_{10}: 0.03$ & & & & \\
\hline & $\mathrm{H}_{20}: 2.22$ & & & & \\
\hline \multirow{2}{*}{ LFRA / LIRE } & $\mathrm{H}_{10}: 0.81$ & $\mathrm{H}_{10}: 3.21$ & $\mathrm{H}_{10}: 4.08$ & $\mathrm{H}_{10}: 3.89$ & $\mathrm{H}_{10}: 1.88$ \\
\hline & $\mathrm{H}_{20}: 4.69$ & $\mathrm{H}_{20}: 4.11$ & $\mathrm{H}_{20}: 5.54$ & $\mathrm{H}_{20}: 7.19$ & $\mathrm{H}_{20}: 0.55$ \\
\hline \multirow{2}{*}{ LFRA / LJAP } & $\mathrm{H}_{10}: 0.22$ & $\mathrm{H}_{10}: 0.07$ & $\mathrm{H}_{10}: 0.07$ & $\mathrm{H}_{10}: 0.07$ & $\mathrm{H}_{10}: 0.06$ \\
\hline & $\mathrm{H}_{20}: 1.87$ & $\mathrm{H}_{20}: 3.53$ & $\mathrm{H}_{20}: 4.81$ & $\mathrm{H}_{20}: 2.07$ & $\mathrm{H}_{20}: 11.51$ \\
\hline \multirow{2}{*}{ LFRA / LSWE } & $\mathrm{H}_{10}: 0.01$ & $\mathrm{H}_{10}: 0.24$ & $\mathrm{H}_{10}: 0.25$ & $\mathrm{H}_{10}: 0.55$ & $\mathrm{H}_{10}: 0.19$ \\
\hline & $\mathrm{H}_{20}: 0.89$ & $\mathrm{H}_{20}: 0.56$ & $\mathrm{H}_{20}: 0.52$ & $\mathrm{H}_{20}: 0.29$ & $\mathrm{H}_{20}: 0.41$ \\
\hline \multirow{2}{*}{ LFRA / LUS } & $\mathrm{H}_{10}: 0.08$ & $\mathrm{H}_{10}: 0.18$ & $\mathrm{H}_{10}: 0.38$ & $\mathrm{H}_{10}: 0.23$ & $\mathrm{H}_{10}: 0.04$ \\
\hline & $\mathrm{H}_{20}: 4.69$ & $\mathrm{H}_{20}: 0.03$ & $\mathrm{H}_{20}: 1.17$ & $\mathrm{H}_{20}: 0.28$ & $\mathrm{H}_{20}: 8.12$ \\
\hline \multirow{2}{*}{ LIRE / LJAP } & $\mathrm{H}_{10}: 1.97$ & $\mathrm{H}_{10}: 0.02$ & $\mathrm{H}_{10}: 0.05$ & $\mathrm{H}_{10}: 0.09$ & $\mathrm{H}_{10}: 0.60$ \\
\hline & $\mathrm{H}_{20}: 2.60$ & $\mathrm{H}_{20}: 4.23$ & $\mathrm{H}_{20}: 4.65$ & $\mathrm{H}_{20}: 3.74$ & $\mathrm{H}_{20}: 42.91$ \\
\hline \multirow{2}{*}{ LIRE / LSWE } & $\mathrm{H}_{10}: 1.90$ & $\mathrm{H}_{10}: 0.06$ & $\mathrm{H}_{10}: 0.01$ & $\mathrm{H}_{10}: 0.01$ & $\mathrm{H}_{10}: 2.59$ \\
\hline & $\mathrm{H}_{20}: 0.86$ & $\mathrm{H}_{20}: 0.09$ & $\mathrm{H}_{20}: 0.05$ & $\mathrm{H}_{20}: 0.65$ & $\mathrm{H}_{20}: 7.00$ \\
\hline \multirow{4}{*}{ LIRE / LUS } & $\mathrm{H}_{10}: 3.66$ & $\mathrm{H}_{10}: 0.03$ & $\mathrm{H}_{10}: 3.15$ & $H_{10}: 15.17$ & $\mathrm{H}_{10}: 7.46$ \\
\hline & $\mathrm{H}_{20}: 2.03$ & $\mathrm{H}_{20}: 1.52$ & $\mathrm{H}_{20}: 0.94$ & $\mathrm{H}_{20}: 9.76$ & $\mathrm{H}_{20}: 4.28$ \\
\hline & $\mathrm{H}_{10}: 0.03$ & & & & \\
\hline & $\mathrm{H}_{20}: 2.22$ & & & & \\
\hline \multirow{2}{*}{ LJAP / LSWE } & $\mathrm{H}_{10}: 5.63$ & $\mathrm{H}_{10}: 1.64$ & $\mathrm{H}_{10}: 6.76$ & $\mathrm{H}_{10}: 2.78$ & $\mathrm{H}_{10}: 0.04$ \\
\hline & $\mathrm{H}_{20}: 25.2$ & $\mathrm{H}_{20}: 12.30$ & $\mathrm{H}_{20}: 23.8$ & $\mathrm{H}_{20}: 8.98$ & $\mathrm{H}_{20}: 24.55$ \\
\hline \multirow{4}{*}{ LJAP / LUS } & $\mathrm{H}_{10}: 5.11$ & $\mathrm{H}_{10}: 1.59$ & $\mathrm{H}_{10}: 2.85$ & $\mathrm{H}_{10}: 4.51$ & $\mathrm{H}_{10}: 41.15$ \\
\hline & $\mathrm{H}_{20}: 4.10$ & $\mathrm{H}_{20}: 5.90$ & $\mathrm{H}_{20}: 10.7$ & $\mathrm{H}_{20}: 12.99$ & $\mathrm{H}_{20}: 0.02$ \\
\hline & $\mathrm{H}_{10}: 0.03$ & & & & \\
\hline & $\mathrm{H}_{20}: 2.22$ & & & & \\
\hline \multirow{2}{*}{ LSWE / LUS } & $\mathrm{H}_{10}: 3.88$ & $\mathrm{H}_{10}: 0.01$ & $\mathrm{H}_{10}: 0.02$ & $\mathrm{H}_{10}: 0.05$ & $\mathrm{H}_{10}: 0.06$ \\
\hline & $\mathrm{H}_{20}: 0.84$ & $\mathrm{H}_{20}: 1.35$ & $\mathrm{H}_{20}: 0.72$ & $\mathrm{H}_{20}: 0.05$ & $\mathrm{H}_{20}: 4.42$ \\
\hline
\end{tabular}

$\chi_{1}^{2}(5 \%)=3.84$. Bold indicates rejection of the null hypothesis of no cointegration at the $5 \%$ level.

Johansen and Nielsen's (2012) FCVAR and Markov-switching copula (Tiwari et al., 2021; Abakah et al., 2021) to investigate further dynamic linkages across countries.

\section{Author statement}

Emmnauel Joel Aikins Abakah proposed the original idea, worked on the literature review and got the dataset; he also contributed with the conclusions.

Guglielmo Maria Caporale wrote the introduction, also participated in the literature review and supervised the whole manuscript.

Luis Alberiko Gil-Alana obtained the empirical results, built the conclusions and supervised the whole manuscript.

\section{References}

Abadir, K.M., Distaso, W., Giraitis, L., 2007. Nonstationarity-extended local Whittle estimation. J. Econom. 141, $1353-1384$.

Abakah, E.J.A., Gil-Alana, L.A., Madigu, G., Romero-Rojo, F., 2020. Volatility persistence in cryptocurrency markets under structural breaks. Int. Rev. Econ. Finance 69, 680-691.

Abakah, E.J.A., Addo Jr, E., Gil-Alana, L.A., Tiwari, A.K., 2021. Re-examination of international bond market dependence: evidence from a pair copula approach. Int. Rev. Financial Anal., 101678

Abbritti, M., Gil-Alana, L., Lovcha, Y., Moreno, A., 2016. Term structure persistence. J. Financ. Econom. 14 (2), $331-352$.

Aghion, P., Rancière, R., Rogoff, K., 2009. Exchange rate volatility and productivity growth: the role of financial development. J. Monetary Econ. 56, 494-513.

Aguiar, M., 2005. Investment, devaluation, and foreign currency exposure: the case of Mexico. J. Dev. Econ. 78, 95-113.

Arbatli, E.C., Davis, S.J., Ito, A., Miake, N., Saito, I., 2017. Policy uncertainty in Japan. IMF Working Paper No. 17/128. https://doi.org/10.5089/ 9781484300671.001.

Bachmann, R., Elstner, S., Sims, E.R., 2013. Uncertainty and economic activity: evidence from business survey data. Am. Econ. J.: Macroecon. 5 (2), 217-249. Bai, J., Perron, P., 2003. Computation and analysis of multiple structural change models. J. Appl. Econom. 18 (1), 1-22.

Bai, L., Zhang, X., Liu, Y., Wang, Q., 2019. Economic risk contagion among major economies: New evidence from EPU spillover analysis in time and frequency domains. Physica A: Stat. Mech. Appl. 535, 122431.

Baillie, R.T., 1996. Long memory processes and fractional integration in econometrics. J. Econom. 73 (1), 5-59.

Baillie, R.T., Bollerslev, T., 1994. Cointegration, fractional cointegration, and exchange rate dynamics. J. Finance 49 (2), $737-745$. 
Baillie, R.T., Calonaci, F., Cho, D., Rho, S., 2019. Long memory, realized volatility and heterogeneous autoregressive models. J.Time Series Anal. 40 (4), 609-628. Baker, S.R., Bloom, N., Canes-Wrone, B., Davis, S.J., Rodden, J., 2014. Why has US policy uncertainty risen since 1960? Am. Econ. Rev. 104 (5), 56-60.

Baker, S.R., Bloom, N., Davis, Steven J., 2016. Measuring economic policy uncertainty. Q. J. Econ. 131, $1593-1636$.

Balcilar, M., Gupta, R., Lee, C.C., Olasehinde-Williams, G., 2020a. Insurance and economic policy uncertainty. Res. Int. Bus. Finance 54, 101253.

Balcilar, M., Ozdemir, Z.A., Ozdemir, H., Wohar, M.E., 2020b. Transmission of US and EU Economic Policy Uncertainty Shock to Asian Economies in Bad and Good Times. Available at SSRN 3602333.

Banerjee, A., Urga, G., 2005. Modelling structural breaks, long memory and stock market volatility: an overview. J. Econom. 129 (1-2), 1-34.

Bansal, R., Yaron, A., 2004. Risks for the long run: a potential resolution of asset pricing puzzles. J. Finance 59 (4), $1481-1509$.

Benigno, G., Benigno, P., Nisticò, S., 2012. Risk, monetary policy, and the exchange rate. NBER Macroecon. Annual 26 (1), $247-309$.

Bernanke, B.S., 1983. Irreversibility, uncertainty, and cyclical investment. Q. J. Econ. 98 (1), 85-106.

Bhagat, S., Ghosh, P., Rangan, S., 2013. Economic policy uncertainty and economic growth in India. Research Paper No. 407. Indian Institute of Management (IIM), Bangalore, India. https://doi.org/10.2139/ssrn.2246882.

Bloom, N., 2009. The impact of uncertainty shocks. Econometrica 77 (3), 623-685.

Bloom, N., Bond, S.R., Van Reenen, J., 2001. The Dynamics of Investment Under Uncertainty. No W01/05. IFS Working Papers from Institute for Fiscal Studies.

Bloomfield, P., 1973. An exponential model in the spectrum of a scalar time series. Biometrika 60, 217-226.

Born, B., Pfeifer, J., 2014. Risk matters: the real effects of volatility shocks: comment. Am. Econ. Rev. 104 (12), $4231-4239$.

Brogaard, J., Detzel, A., 2015. The asset-pricing implications of government economic policy uncertainty. Manage. Sci. 61, 3-18.

Caggiano, G., Castelnuovo, E., Figueres, J.M., 2020. Economic policy uncertainty spillovers in booms and busts. Oxf. Bull. Econ. Stat. 82 (1), $125-155$.

Caporale, G.M., Gil-Alana, L.A., 2002. Fractional integration and mean reversion in stock prices. Q. Rev. Econ. Finance 42 (3), $599-609$.

Carriero, A., Clark, T.E., Marcellino, M., 2018. Measuring uncertainty and its impact on the economy. Rev. Econ. Stat. 100 (5), $799-815$.

Carroll, C.D., 1997. Buffer-stock saving and the life cycle/permanent income hypothesis. Q. J. Econ. 112 (1), 1-55.

Castelnuovo, E., Tran, T.D., 2017. Google it up! A google trends-based uncertainty index for the United States and Australia. Econ. Lett. $161,149-153$.

Cekin, S.E., Pradhan, A.K., Tiwari, A.K., Gupta, R., 2020. Measuring co-dependencies of economic policy uncertainty in Latin American countries using vine copulas. Q. Rev. Econ. Finance 76, 207-217.

Cerda, R., Silva, A., Valente, J.T., 2016. Economic uncertainty impact in a small open economy: the case of Chile. Applied Economics. https://doi.org/10.1080/ 00036846.2017.1412076. Published online 07 December 2017.

Cheung, Y.W., Lai, K.S., 1993. A fractional cointegration analysis of purchasing power parity. J. Bus. Econ. Stat. 11, 103-112.

Creal, D.D., Wu, J.C., 2017. Monetary policy uncertainty and economic fluctuations. Int. Econ. Rev. 58 (4), $1317-1354$.

Diebold, F.X., Inoue, A., 2001. Long memory and regime switching. J. Econom. 105 (1), 131-159.

Diebold, F.X., Yilmaz, K., 2012. Better to give than to receive: Predictive directional measurement of volatility spillovers. Int. J. Forecast. 28 (1), 57-66.

Diebold, F.X., Yilmaz, K., 2014. On the network topology of variance decompositions: Measuring the connectedness of financial firms. J. Econom. 182 (1), $119-134$.

Dixit, A., 1989. Entry and exit decisions under uncertainty. J. Polit. Econ. 97 (3), 620-638.

Dixit, R.K., Pindyck, R.S., 1994. Investment Under Uncertainty. Princeton University Press.

Dueker, M., Startz, R., 1998. Maximum-likelihood estimation of fractional cointegration with an application to US and Canadian bond rates. Rev. Econ. Stat. 80 (3), $420-426$.

Engle, R.F., Granger, C.W.J., 1987. Co-integration and error correction: representation, estimation, and testing. Econometrica 55 (2), 251-276. https://doi.org/ $10.2307 / 1913236$.

Fernandez, R., Rodrik, D., 1991. Resistance to reform: Status quo bias in the presence of individual-specific uncertainty. Am. Econ. Rev. $1146-1155$.

Fernández-Villaverde, J., Guerrón-Quintana, P., Rubio-Ramirez, J.F., Uribe, M., 2011. Risk matters: the real effects of volatility shocks. Am. Econ. Rev. 101 (6), 2530-2561.

Gil-Alana, L.A., 2003. Testing of fractional cointegration in macroeconomic time series. Oxf. Bull. Econ. Stat. 65 (4), 517-529. https://doi.org/10.1111/1468-0084. t01-1-00048.

Gil-Alana, L.A., 2008. Fractional integration and structural breaks at unknown periods of time. J. Time Ser. Anal. 29 (1), $163-185$.

Gil-Alana, L.A., Moreno, A., 2012. Uncovering the US term premium: an alternative route. J. Bank. Finance 36 (4), 1181-1193.

Gil-Alana, L.A., Payne, J.E., 2020. Measuring the degree of persistence in the US economic policy uncertainty index. Appl. Econ. Lett. 27 (10), $831-835$.

Gil-Alana, L.A., Robinson, P.M., 1997. Testing of unit roots and other nonstationary hypotheses in macroeconomic time series. J. Econom. 80 , 241-268.

Gil-Alana, L., Carcel, H., Abakah, E.J.A., 2018. On the linkages between Africa's emerging equity markets and global markets: evidence from fractional integration and cointegration. Review of development finance 8 (2), 96-105.

Gil-Alana, L.A., Abakah, E.J.A., Abakah, M.K., 2020a. Financial stress spillover across Asian countries. Rev. Financ. Econo.

Gil-Alana, L.A., Abakah, E.J.A., Rojo, M.F.R., 2020b. Cryptocurrencies and stock market indices. Are they related? Res. Int. Bus. Finance 51, 101063.

Gil-Alana, L.A., Mudida, R., Abakah, E.J.A., 2020c. Are central bank policy rates in Africa cointegrated? Evidence from a fractional cointegration approach. Appl. Econ. 52 (57), 6171-6182.

Gilchrist, S., Williams, J.C., 2005. Investment, capacity, and uncertainty: a putty-clay approach. Rev. Econ. Dyn. 8 (1), 1-27.

Gourinchas, P.-O., Parker, J.A., 2002. Consumption over the life cycle. Econometrica 70, 47-89.

Gourio, F., 2013. Financial distress and endogenous uncertainty. Meeting Papers (No. 108). Society for Economic Dynamics.

Granger, C.W., 1980. Testing for causality: a personal viewpoint. J. Econ. Dyn. Control 2, 329-352.

Granger, C.W., Hyung, N., 2004. Occasional structural breaks and long memory with an application to the S\&P 500 absolute stock returns. J. Emp. Finance 11 (3), 399-421.

Guiso, L., Jappelli, T., Padula, M., 2013. Pension wealth uncertainty. J. Risk Insur. 80 (4), 1057-1085.

Gulen, H., Ion, M., 2016. Policy uncertainty and corporate investment. Rev. Financ. Stud. 29 (3), 523-564.

He, Z., Niu, J., 2018. The effect of economic policy uncertainty on bank valuations. Appl. Econ. Lett. 25 (5), $345-347$.

Hlatshwayo, S., Saxegaard, M., 2016. The consequences of policy uncertainty: disconnects and dilutions in the South African Real effective Exchange rate-export relationship. IMF Working Paper No. 16/113. https://doi.org/10.5089/9781484383490.001.

Husted, L., Rogers, J., Sun, B., 2018. Uncertainty, currency excess returns, and risk reversals. J. Int. Money Finance 88, $228-241$.

Istiak, K., Serletis, A., 2018. Economic policy uncertainty and real output: evidence from the G7 countries. Appl. Econ. 50 (39), $4222-4233$.

Istrefi, K., Mouabbi, S., 2018. Subjective interest rate uncertainty and the macroeconomy: a cross-country analysis. J. Int. Money Finance 88, $296-313$.

Johansen, S., 1988. Statistical analysis of cointegration vectors. J. Econ. Dyn. Control 12 (2-3), 231-254.

Johansen, S., 1991. Estimation and hypothesis testing of cointegration vectors in Gaussian vector autoregressive models. Econometrica 59 (6), 1551-1580.

Johansen, S., 1995. Likelihood-Based Inference in Cointegrated Vector Autoregressive Models. Oxford University Press, New York.

Johansen, S., Juselius, K., 1994. Identification of the long-run and short-run structure: an application of the ISLM model. J. Econom. 63, 7-36.

Johansen, S., Nielsen, M.Ø., 2010. Likelihood inference for a nonstationary fractional autoregressive model. J. Econometr. 158, 51-66.

Johansen, S., Nielsen, M.Ø., 2012. Likelihood inference for a fractionally cointegrated vector autoregressive model. Econometrica 80 (6), $2667-2732$.

Jurado, K., Ludvigson, S.C., Ng, S., 2015. Measuring uncertainty. Am. Econ. Rev. 105 (3), 1177-1216.

Kane, E.J., 2000. Capital movements, banking insolvency, and silent runs in the Asian financial crisis. Pac.-Basin Finance J. 8, $153-175$.

Kang, W., Lee, K., Ratti, R.A., 2014. Economic policy uncertainty and firm-level investment. J. Macroecon. 39, $42-53$.

Klößner, S., Sekkel, R., 2014. International spillovers of policy uncertainty. Econ. Lett. 124 (3), 508-512.

Ko, J.H., Lee, C.M., 2015. International economic policy uncertainty and stock prices: wavelet approach. Econ. Lett. 134, 118-122.

Kroese, L., Kok, S., Parlevliet, J., 2015. Beleidsonzekerheid in Nederland. Economisch Statistiche Berichten 4715, 464-467.

Kydland, F.E., Zarazaga, C.E.J.M., 2016. Fiscal sentiment and the weak recovery from the Great recession: a quantitative exploration. J. Monet. Econ. 79, 109-125. 
Leduc, S., Liu, Z., 2016. Uncertainty shocks are aggregate demand shocks. J. Monet. Econ. 82, 20-35.

Ludvigson, S.C., Ma, S., Ng, S., 2017. Shock Restricted Structural Vector-Autoregressions (No. w23225). National Bureau of Economic Research.

Luk, P., Cheng, M., Ng, P., Wong, K., 2020. Economic policy uncertainty spillovers in small open economies: the case of Hong Kong. Pac. Econ. Rev. 25 (1), 21-46.

Luo, Y., Zhang, C., 2020. Economic policy uncertainty and stock price crash risk". Res. Int. Bus. Finance 51, 101112.

Marinucci, D., Robinson, P.M., 2001. Semiparametric fractional cointegration analysis. J. Econom. 105, $225-247$.

Mayoral, L., 2006. Further evidence on the statistical properties of real GNP. Oxf. Bull. Econ. Stat. 68, 901-920.

McDonald, R., Siegel, D., 1986. The value of waiting to invest. Q. J. Econ. 101 (4), 707-727.

Nelson, C., Plosser, C., 1982. Trends and random walks in macroeconmic time series: some evidence and implications. J. Monet. Econ. 10 (2), $139-162$.

Nguyen, C.P., Thai-Ha, L., Dinh Su, T., 2020. Economic policy uncertainty and credit growth: evidence from a global sample". Res. Int. Bus. Finance 51, 101118.

Osei, P.M., Djimatey, R., Adam, A.M., 2021. Economic Policy Uncertainty Linkages among Asian Countries: Evidence from Threshold Cointegration Approach. Discrete Dynamics in Nature and Society.

Pastor, L., Veronesi, P., 2012. Uncertainty about government policy and stock prices. J. Finance 67 (4), $1219-1264$.

Pastor, L., Veronesi, P., 2013. Political uncertainty and risk premia. J. Financ. Econ. 110 (3), 520-545.

Phillips, P.C., Shimotsu, K., 2005. Exact local Whittle estimation of fractional integration. Ann. Stat. 33, $1890-1933$.

Prüser, J., Schlösser, A., 2020. On the time-varying effects of economic policy uncertainty on the US economy. Oxf. Bull. Econ. Stat. 82 (5), $1217-1237$.

Robinson, P.M., 1994. Efficient tests of nonstationary hypotheses. J. Am. Stat. Assoc. 89, 1420-1437.

Robinson, P.M., 1995. Gaussian semiparametric estimation of long range dependence. Ann. Stat. 23 (5), $1630-1661$.

Robinson, P.M., Hualde, J., 2003. Cointegration in fractional systems with unknown integration orders. Econometrica 71 (6), $1727-1766$.

Robinson, P.M., Yajima, Y., 2002. Determination of cointegrating rank in fractional systems. J. Econom. 106 (2), $217-241$.

Rossi, B., Sekhposyan, T., 2016. Forecast rationality tests in the presence of instabilities, with applications to Federal Reserve and survey forecasts. J. Appl. Econom. 31 (3), 507-532.

Sahinoz, S., Cosar, E., 2018. Economic policy uncertainty and economic activity in Turkey. Appl. Econ. Lett. 25 (21), 1517-1520.

Scotti, C., 2016. Surprise and uncertainty indexes: real-time aggregation of real-activity macro-surprises. J. Monet. Econ. 82, 1-19.

Shoag, D., Veuger, S., 2016. Uncertainty and the geography of the Great recession. J. Monet. Econ. 84, 84-93.

Sinha, A., 2016. Monetary policy uncertainty and investor expectations. J. Macroecon. 47, 188-199.

Solarin, S.A., Gil-Alana, L.A., 2021. The persistence of economic policy uncertainty: evidence of long range dependence. Phys. A: Stat. Mech. Appl. 568, 125698.

Thiem, C., 2018. Cross-Category Spillovers of Economic Policy Uncertainty (No. 744). Ruhr Economic Papers.

Tiwari, A.K., Abakah, E.J.A., Le, T.L., Leyva-de la Hiz, D.I., 2021. Markov-switching dependence between artificial intelligence and carbon price: the role of policy uncertainty in The era of The 4th industrial revolution and The effect of COVID-19 pandemic. Technol. Forecasting Social Change 163 , 120434.

Velasco, C., 1999. Gaussian semiparametric estimation of nonstationary time series. J. Time Ser. Anal. 20, 87-127.

Zalla, R., 2017. Economic policy uncertainty in Ireland. Atlantic Econ. J. 45, 269-271. https://doi.org/10.1007/s11293-017-9536-9538. 